\title{
$\begin{array}{llllllllllllllllll}\mathbf{O} & \mathbf{M} & \boldsymbol{O} & \mathbf{W} & \mathbf{I} & \mathbf{E} & \mathbf{N} & \mathbf{I} & \mathbf{A} & \mathbf{I} & \mathbf{R} & \mathbf{E} & \mathbf{C} & \mathbf{E} & \mathbf{N} & \mathbf{Z} & \mathbf{J} & \mathbf{E}\end{array}$
}

ARCHEION, T. CXXI

WARSZAWA 2020

ISSN 0066-6041

e-ISSN 2658-1264

DOI 10.4467/26581264ARC.20.018.12975

ANDRZEJ KWAŚNIEWSKI

ORCID $\underline{\text { 0000-0001-7174-2122 }}$

andrzej220777@wp.pl

(Towarzystwo Przyjaciół Archiwum Diecezjalnego imienia błogosławionego Wincentego Kadłubka w Kielcach, Uniwersytet Kardynała Stefana Wyszyńskiego w Warszawie)

\section{ZNACZENIE KATALOGU MIKROFILMÓW KOŚCIELNYCH ARCHIWALIÓW ORAZ ZBIORÓW LITURGICZNYCH I BIBLIOTECZNYCH. RECENZJA OPRACOWANIA KATALOG MIKROFILMÓW OŚRODKA ARCHIWÓW, BIBLIOTEK I MUZEÓW KOŚCIELNYCH KATOLICKIEGO UNIWERSYTETU LUBELSKIEGO JANA PAWLA II, oprac. M. Dębowska, Wydawnictwo Instytutu Teologicznego Księży Misjonarzy w Krakowie, Kraków 2017, ss. 677}

Słowa kluczowe: archiwistyka, Ośrodek Archiwów, Bibliotek i Muzeów Kościelnych Katolickiego Uniwersytetu Lubelskiego, Dębowska Maria, Kumor Bolesław, zasób polskich archiwów kościelnych, zbiory historyczne bibliotek kościelnych, kościelne dobra kultury.

\section{Streszczenie}

Ośrodek Archiwów, Bibliotek i Muzeów Kościelnych Katolickiego Uniwersytetu Lubelskiego Jana Pawła II prowadził od roku 1960 prace polegające na mikrofilmowaniu głównie kościelnych archiwaliów oraz - w mniejszym stopniu - zbiorów historycznych bibliotek kościelnych. Opisy gromadzonych mikrofilmów były na przestrzeni lat publikowane na łamach czasopisma „Archiwa, Biblioteki i Muzea Kościelne”. Poszczególne grupy mikrofilmów zyskiwały kolejny numer publikacji nazywanej katalogiem mikrofilmów. Obecny stan prac został przedstawiony w drukowanym katalogu autorstwa dr hab. Marii Dębowskiej. Publikacja scaliła opisy 5593 mikrofilmów. Ich kolekcja, stworzona w Ośrodku Archiwów, Bibliotek i Muzeów Kościelnych, jest unikatowym zbiorem do badań nad dziejami Kościoła w Polsce. 
ANDRZEJ KWAŚNIEWSKI

ORCID $\underline{0000-0001-7174-2122}$

andrzej220777@wp.pl

(The Blessed Wincenty Kadłubek Society of Friends of the Diocesan Archive in Kielce, University of Cardinal Stefan Wyszyński in Warsaw)

\section{THE SIGNIFICANCE OF AN ARCHIVE ECCLESIASTICAL MICROFILM CATALOGUE AND OF LITURGY AND LIBRARY COLLECTIONS. REVIEW OF THE PUBLICATION MICROFILM CATALOGUE IN POSSESSION OF THE ECCLESIASTICAL ARCHIVES, LIBRARY AND MUSEUM CENTRE OF THE JOHN PAUL II CATHOLIC UNIVERSITY OF LUBLIN, COMPILED BY MARIA DĘBOWSKA, Publishing House of Instytut Teologiczny Księży Misjonarzy in Cracow, Cracow 2017, pp. 677}

Keywords: archival science, Ecclesiastical Archives, Library and Museum Centre of the John Paul II Catholic University of Lublin, Maria Dębowska, Bolesław Kumor, Polish ecclesiastical archival fonds, collections of historical church libraries, church cultural values.

\footnotetext{
Abstract

Ever since 1960, the Ecclesiastical Archives, Library and Museum Centre of the John Paul II Catholic University of Lublin has been microfilming primarily ecclesiastical archive materials and partially also the historical collections of church libraries. The descriptions of the resulting microfilms were published over the years in the journal Archiwa, Biblioteki i Muzea Kościelne. Subsequent groups of microfilms were assigned consecutive publication numbers and were referred to as microfilm catalogues. The current status of the work is presented in a printed catalogue by Maria Dębowska, $\mathrm{PhD}$. The catalogue brings together descriptions of 5,593 microfilms. Created in the Ecclesiastical Archives, Library and Museum Centre, the microfilm collection is a unique resource for studies on the history of the Church in Poland.
} 
Prace mikrofilmowania archiwaliów kościelnych w Ośrodku Archiwów, Bibliotek i Muzeów Kościelnych Katolickiego Uniwersytetu Lubelskiego (dalej: Ośrodek ABMK) rozpoczął ks. prof. Bolesław Kumor w 1960 r. Owocnie prowadzona akcja była prezentowana przez niego na forum archiwistów polskich i stała się przedmiotem artykułu opublikowanego w 1972 r. ${ }^{1}$ Kilka lat później ks. B. Kumor wygłosił referat na naradzie pt. „Zastosowanie mikroform w bibliotekarstwie i informacji naukowej", która odbyła się w Warszawie 5-6 grudnia 1978 r. Zorganizowały ją Zarząd Sekcji Nauki Związku Nauczycielstwa Polskiego - Komisja Pracowników Informacji Naukowej oraz Zarząd Główny Stowarzyszenia Bibliotekarzy Polskich - Komisja ds. Mikrofilmowania Zbiorów Bibliotecznych².

Mikrofilmowanie było kontynuowane przez lata. Dr hab. Maria Dębowska, jako wieloletni pracownik Ośrodka ABMK, zdobyła w tej kwestii duże doświadczenie, pozwalające na przedstawienie całokształtu prac nad mikrofilmowaniem. Umożliwiło jej to opublikowanie artykułów omawiających trwający kilkadziesiąt lat proces mikrofilmowania akt poszczególnych archiwów i zbiorów bibliotecznych ${ }^{3}$. Artykuły te pozwalają na zapoznanie się z okolicznościami wielkiej pracy, jaką wykonano w Ośrodku ABMK.

Największą liczbę mikrofilmów jednostek archiwalnych zgromadzono z archiwów należących do (archi)diecezji w: Krakowie, Kielcach, Lublinie, Olsztynie, Pelplinie, Płocku, Przemyślu, Siedlcach, Tarnowie i Włocławku. Niewielka liczba jednostek została pozyskana do zmikrofilmowania z Gniezna, Poznania i Warszawy. Współpracy nie nawiązano z Archiwum Archidiecezjalnym i Biblioteką Kapitulną we Wrocławiu. Przedmiotem zainteresowania były najważniejsze wytwory kościelnych kancelarii: protokoły wizytacyjne, acta episcopalia, acta administratoria, acta officialia, akta kapitut, akta konsystorzy. Pewnym wyjątkiem w kolekcjonowaniu mikrofilmów staropolskich akt było zmikrofilmowanie dziewiętnastowiecznej kancelarii konsystorza tarnowskiego oraz archiwaliów lwowskich, lubelskich i siedleckich. Obok archiwów poszczególnych diecezji, zmikrofilmowano zbiory zakonne: paulinów - Częstochowa, norbertanek - Imbramowice, franciszkanów konwentualnych - Warszawa, klarysek - Stary Sącz, benedyktynek - Staniątki. Słabo reprezentowane są archiwa parafialne. Z ar-

${ }^{1}$ B. Kumor, Rola Ośrodka Archiwów, Bibliotek i Muzeów Kościelnych przy KUL w udostęnianiu kościelnych zbiorów archiwalnych nauce polskiej, [w:] Materiaty sesji „Archiwa warsztatem pracy historyka", cz. 2, Toruń 1972, s. 69-73.

2 Idem, Mikrofilmowanie zbiorów kościelnych przez Ośrodek Archiwów, Bibliotek i Muzeów Kościelnych, „Archiwa, Biblioteki i Muzea Kościelne” (dalej: ABMK) 1980, t. 40, s. 119-122.

${ }^{3}$ M. Dębowska, Mikrofilmowanie zbiorów kościelnych w Instytucie Archiwów, Bibliotek i Muzeów Kościelnych Katolickiego Uniwersytetu Lubelskiego Jana Pawła II, [w:] Archiwa w nowoczesnym społeczeństwie. Pamiętnik V Powszechnego Zjazdu Archiwistów Polskich Olsztyn 6-8 września 2007 r., red. J. Porazinski, K. Stryjkowski, Warszawa 2008, s. 109-116; eadem, Mikrofilmowanie materiatów archiwalnych $w$ archiwach kościelnych, [w:] Ochrona zasobu archiwów kościelnych, red. A. Laszuk, Warszawa 2012, s. 160-169. 
chiwów państwowych zmikrofilmowano akta dotyczące wybranych instytucji kościelnych. Ponadto mikrofilmowaniem objęto jednostki związane z dziejami Kościoła w Polsce $\mathrm{z}$ archiwów zagranicznych. Większość z nich pochodziła $\mathrm{z}$ archiwum watykańskiego. W Ośrodku ABMK, obok archiwaliów, występuje znacznie mniejsza grupa zmikrofilmowanych zbiorów bibliotecznych. Są to przede wszystkim zbiory nowożytne oraz - w mniejszym stopniu - średniowieczne i współczesne: rękopisy liturgiczne, rękopisy biblioteczne (głównie teologiczne), starodruki liturgiczne (m. in. księgi rzymskie i księgi chorału piotrkowskiego), starodruki biblioteczne, rękopisy i druki pieśni religijnych, starodruki prawne (synody) $\mathrm{i}$ inne.

Analiza procesu i zakresu mikrofilmowania prowadzi do wniosku, że typowanie poszczególnych grup archiwaliów wykazuje realną zależność od warsztatu naukowego ks. B. Kumora, który zrealizował znaczną część prac. Bardzo dobrze zmikrofilmowany jest zasób wytworzony na terytorium dawnej diecezji krakowskiej. Zmikrofilmowano największy zbiór ksiąg wizytacyjnych znajdujący się w Archiwum Kurii Metropolitalnej w Krakowie wraz z depozytem kapituły krakowskiej. Ponadto pracami objęto acta episcopalia, acta administratoria i acta officialia. Z zasobu Archiwum Diecezjalnego w Kielcach, związanego tematycznie i instytucjonalnie z dawną diecezją krakowską, wybrano i w całości zmikrofilmowano najcenniejsze księgi wytworzone $\mathrm{m}$. in. przez oficjalaty i kapituły. Większą grupę mikrofilmów stanowią wspomniane wyżej akta konsystorza tarnowskiego. Dwie grupy archiwaliów związanych z dawną diecezją krakowską i diecezją tarnowską były podstawą źródłową dorobku naukowego ks. B. Kumora ${ }^{4}$. Z drugiej strony okazało się, że staropolskie akta krakowskie, zmikrofilmowane ze względu na potrzeby warsztatu naukowego ks. B. Kumora, cieszą się największym zainteresowaniem badaczy. Z kolei mikrofilmy akt dziewiętnastowiecznego konsystorza tarnowskiego nie cieszą się popularnością wśród kwerendzistów i właściwie nikt z nich nie korzystał ${ }^{5}$.

Zgodnie $\mathrm{z}$ założeniami, $\mathrm{w}$ procesie mikrofilmowania wzięto pod uwagę przede wszystkim jednostki archiwalne wytworzone w nowożytności i plan ten w praktyce zrealizowano. Trwające po dzień dzisiejszy prace doprowadziły do stworzenia jedynego w Polsce, niepowtarzalnego i olbrzymiego zbioru mikrofilmów najcenniejszych archiwaliów kościelnych. Zbiór mikrofilmów liturgicznych i bibliotecznych rękopisów i starodruków, jako grupa nieporównywalnie mniejsza od zbioru mikrofilmów archiwaliów, stanowi jednak cenną kolekcję do badań kodykologicznych, muzykologicznych i liturgicznych. Jest najkompletniejszą kolekcją mikrofilmów zbiorów liturgicznych i bibliotecznych w Polsce.

${ }^{4}$ Zob.: A. Kwaśniewski, Podręczniki do historii Kościoła i wybrane monografie księdza profesora Bolestawa Kumora, [w:] Ksiądz profesor Bolesław Kumor 1925-2002. Historyk Kościoła i dydaktyk, red. W. Żurek, Lublin 2018, s. 53-76.

${ }^{5}$ Informacje z rozmów przeprowadzonych z pracownikami Ośrodka ABMK. 
Stworzenie zbioru mikrofilmów można uznać za największe osiągnięcie Ośrodka ABMK, który wpłynął na kierunki badań historycznych dzięki udostępnieniu zawartości źródeł. Poprzez mikrofilmowanie wytyczono drogi realizacji zainteresowań naukowych. W praktyce w ciągu kilku tygodni pracy możliwe stało się rozczytanie i robocze przepisanie wyselekcjonowanych wcześniej źródeł potrzebnych do rozprawy naukowej. Do odczytywania mikrofilmów najczęściej wykorzystywano rzutniki Ośrodka ABMK. Stosowano też wypożyczanie mikrofilmów. W latach 60 . XX w. był to epokowy przełom w pracy na źródłach. Pracownicy ośrodka, pomyślanego jako metodyczny dla polskiej archiwistyki kościelnej, udostępniali źródła bez ograniczeń, służyli radą naukową. Praca ta wytworzyła nowy model obsługi kwerendzistów. Wobec różnych zasad postępowania w archiwach kościelnych, a często praktycznej niedostępności źródeł, praca udostępniania prowadzona w Ośrodku ABMK zmniejszyła dotkliwe braki wynikające ze skromnej kadry archiwów kościelnych.

Po wykonaniu zaplanowanej, większej części akcji mikrofilmowania, opracowano drukowany katalog mikrofilmów. Pierwsze cztery katalogi przygotował ks. B. Kumor, piąty ks. Janusz Kania, szósty i siódmy M. Dębowska. Część mikrofilmów najnowszych, $\mathrm{m}$. in akta nuncjatury warszawskiej, czekały na sporządzenie katalogu. W takich okolicznościach $\mathrm{M}$. Dębowska pojęła pracę nad scaleniem zawartości wydrukowanych katalogów i dodaniem opisów najnowszych mikrofilmów, które nie były wykazane we wcześniejszych katalogach. Obok scalenia kilku katalogów dokonano sprawdzenia faktycznie istniejących w ośrodku mikrofilmów i usunięto opisy mikrofilmów zaginionych. Omawiany katalog zawiera opisy mikrofilmów 5593 jednostek archiwalnych oraz zbiorów bibliotecznych (głównie rękopisów i druków - liturgicznych, teologicznych i prawnych).

Redaktor techniczny publikacji, dr Artur Hamryszczak, jako długoletni pracownik (obecnie pełniący obowiązki dyrektor Ośrodka ABMK), był odpowiedzialny za przygotowanie do druku omawianego katalogu mikrofilmów. Dodatkowo pomagał M. Dębowskiej w ich uporządkowaniu. W ramach tej współpracy przeprowadzono skontrum kolekcji mikrofilmów i rozpoznano kwestie wątpliwe (zły opis, sygnatury itp.). Ponadto zabezpieczono mikrofilmy poprzez usunięcie $\mathrm{z}$ ich powierzchni zabrudzeń (umycie) oraz zakupiono profesjonalne pudełka bezkwasowe, do których je przepakowano. Dzięki tym działaniom nie tylko ustalono jakie mikrofilmy są faktycznie przechowywane w Ośrodku ABMK, ale i zapewniono ich prawidłowe przechowywanie, zgodnie z obowiązującymi zasadami i na miarę możliwości technicznych, jakimi można obecnie dysponować

Wydawnictwo poprzedzone jest wprowadzeniem, w którym w sposób skrótowy przedstawiono problematykę prac Ośrodka ABMK. Przytoczono w nim

${ }^{6}$ Archiwum Ośrodka Archiwów, Bibliotek i Muzeów Kościelnych, Mikrofilmowanie archiwaliów, Skontrum mikrofilmów OABMK 2015-2016, b. sygn. 
literaturę, jednak, ze szkodą dla korzystających, zbyt lakonicznie; przywołuje się dane konieczne do pobieżnego zrozumienia sensu dzieła. Podobnie skromnie opisana jest praca własna autorki nad katalogiem. Po wstępie zamieszczony został wykaz skrótów i właściwy katalog, podzielony na trzy części.

Część pierwsza - instytucje naukowe w Polsce. Występują tu archiwa diecezjalne, kapitulne, zakonne, parafialne, państwowe i archiwa prywatne. Archiwa diecezjalne reprezentowane są licznie - 17 instytucji. Liczba ta obejmuje większość archiwów polskich przechowujących średniowieczny i nowożytny zasób, m. in. krakowskie, gnieźnieńskie, włocławskie, płockie, warmińskie, pelplińskie i inne. Jest to najważniejsza część katalogu o znaczeniu ogólnopolskim. Występują tu cenniejsze i reprezentatywne archiwalia, w tym akta: kapituł, wizytacji generalnych, czynności biskupów, konsystorzy generalnych i foralnych. Archiwa kapitulne reprezentowane są jedynie przez kapituły krakowską i łowicką. $\mathrm{Z}$ ich zasobu zmikrofilmowano tylko niewielką cześć jednostek archiwalnych. W grupie archiwów zakonnych występuje 6 instytucji. Wśród archiwów klasztornych wyróżniają się pod względem liczby zmikrofilmowanych jednostek Archiwum Norbertanek w Imbramowicach i Archiwum Paulinów na Jasnej Górze. Z archiwów państwowych mamy dwa - Archiwum Państwowe w Lublinie i Archiwum Państwowe w Poznaniu. Zmikrofilmowane akta z archiwum lubelskiego to głównie obszerny zespół o nazwie Kapituła Kolegiacka w Zamościu oraz kilka jednostek wytworzonych $\mathrm{m}$. in. przez zakony i instytucje świeckie. Zmikrofilmowane akta $\mathrm{z}$ archiwum poznańskiego to trzy jednostki dotyczące klasztoru w Lubiniu. Zbiory prywatne obejmują zaledwie dwie jednostki na temat archidiecezji lwowskiej i wypisów źródłowych poruszających zagadnienie historii Kościoła w Polsce.

Oprócz archiwów, katalog obejmuje znaczącą grupę zbiorów z 11 bibliotek kościelnych (seminaryjnych i klasztornych) i 8 państwowych. Ich analiza wskazuje na kryteria wyznaczania poszczególnych obiektów do mikrofilmowania. Z bibliotek kościelnych wyselekcjonowano rękopisy i starodruki (teologiczne i liturgiczne). Z bibliotek państwowych wybrano archiwalia należące do zespołów wytworzonych przez instytucje kościelne. $Z$ pewnych względów archiwalia te zostały odłączone przez prywatnych użytkowników od zespołów przechowywanych w archiwach kościelnych i znalazły się w bibliotekach państwowych. Prawdopodobnie dzięki temu zostały ocalone od zniszczenia. Wykonanie mikrofilmów tych jednostek archiwalnych pozwala wstępnie zorientować się w kwestii miejsc ich przechowywania tych szczątkowych zespołów w bibliotekach niekościelnych.

W łączności ze zbiorami bibliotecznymi pozostają dwie kolekcje: muzykalia i statuty synodalne. Kolekcja statutów synodalnych odznacza się dość konsekwentną budową. Obejmuje bowiem większość edycji nowożytnych statutów Kościoła w Polsce. Edycje te przechowywane są w Bibliotece Katolickiego Uniwersytetu Lubelskiego oraz m. in. w bibliotekach seminaryjnych. 
Kolekcja muzykaliów zawiera druki i rękopisy liturgiczne od XVI do XIX w. Zmikrofilmowane obiekty pochodzą z różnych instytucji. Jednak znaczna część mikrofilmów z bibliotek kościelnych zaklasyfikowana do poszczególnych instytucji mogłaby być wcielona do kolekcji muzycznej. Mamy tu przykład dwóch różnych koncepcji działania ośrodka ABMK. Cześć zbiorów uszeregowano pod instytucjami, a część wydzielono niekonsekwentnie w kolekcję muzyczną.

Część druga katalogu dotyczy zagranicznych instytucji naukowych (archiwów i bibliotek). Największa liczba zmikrofilmowanych jednostek archiwalnych pochodzi z Archivum Secretum Vaticanum w Rzymie. Liczną grupę stanowią tam akta procesów informacyjnych biskupów polskich. Druga znacząca część to akta nuncjatury polskiej. Mniej liczne są akta kanonizacyjne. Z zasobu zagranicznych archiwów zmikrofilmowano również jednostki wybranych zakonnych archiwów rzymskich (dominikanów, paulinów, teatynów, trynitarzy). W skromnej skali reprezentowane są biblioteki zagraniczne - Biblioteka Narodowa w Paryżu i Biblioteka Casanatense w Rzymie. Kilkanaście jednostek $\mathrm{z}$ bibliotek zagranicznych dotyczy $\mathrm{m}$. in. procesów kanonizacyjnych polskich świętych.

W trzeciej części, zatytułowanej „Uzupełnienia”, znajdują się zmikrofilmowane obiekty z instytucji krajowych i zagranicznych. Najważniejszą grupę stanowią materiały Archiwum Diecezji Łuckiej w Lublinie. Jednostki te różnią się od kwalifikowanych wcześniej do mikrofilmowania, zostały bowiem wytworzone w XX w. Druga ważna kolekcja to mikrofilmy jednostek z Archivum Secretum Vaticanum w Rzymie. Jest to grupa nowożytnych relacji biskupich na temat stanu diecezji. Inne pozycje tej części katalogu nie wskazują na żadne nowe większe prace odznaczające się wyrazistą koncepcją. Są jedynie dopełnieniem już występujących grup archiwaliów pochodzących z instytucji objętych wcześniej mikrofilmowaniem.

Jednym z ważniejszych problemów, przed którym stanęła autorka katalogu, było zagadnienie zespołowości. Archiwalia kościelne ciągle pozostają bowiem na bardzo niskim stopniu rozpoznania i podziału na zespoły. Np. w Archiwum Diecezjalnym w Kielcach akta kapituły wiślickiej i kurzelowskiej pomieszane są z aktami oficjalatu. Są to dwie kolekcje nowożytnych archiwaliów - odpowiednio kapituły wiślickiej i oficjalatu wiślickiego oraz kapituły kurzelowskiej i oficjalatu kurzelowskiego. Faktycznie powinny to być cztery zespoły archiwalne z dwóch miejscowości. Podobnie pomieszane są akta kapituły kieleckiej (staropolskie i dziewiętnastowieczne) z aktami dziewiętnastowiecznego oficjalatu kieleckiego. Autorka katalogu dokonała w swojej pracy podziału zmikrofilmowanych akt kolekcji wiślickiej i kolekcji kurzelowskiej na cztery zespoły, można by rzec - wirtualne (s. 19-21). Podobnie podzieliła akta kieleckie na dwa zespoły - kapituła i konsystorz, dodatkowo z akt kapitulnych wydzieliła zespół Kapituła Katedralna w Tarnowie (s. 18-19). 
Dokonując dzielenia na zespoły, autorka stawała również przed koniecznością podjęcia trudnych i niezgodnych z doktryną archiwistyczną decyzji. Np. mikrofilm akt parafii Beszowa, znajdujących się dawniej w Archiwum Diecezjalnym w Kielcach, umieściła w grupie mikrofilmów tegoż archiwum (s. 21). Jednak obecnie akta parafii Beszowa nie są przechowywane w archiwum kieleckim. Być może po zmikrofilmowaniu przekazano je do Archiwum Diecezjalnego w Sandomierzu? Trudno jednak tego dociec bez przeprowadzonych badań. Podobny problem dotyczy akt przechowywanych w Archiwum Diecezji Sosnowieckiej im. ks. Jerzego Wolnego w Sosnowcu. Po utworzeniu diecezji sosnowieckiej, z Archiwum Diecezjalnego w Kiecach przekazano do niego zespoły instytucji kościelnych z terenu, który z diecezji kieleckiej został włączony do diecezji sosnowieckiej. Akta te w tworzącym się archiwum sosnowieckim nie otrzymały do tej pory sygnatur, więc posiadają nadal stare sygnatury kieleckie (s. 296-297). Zgodnie z zasadami wykazano je jednak jako przechowywane w Sosnowcu. W momencie, w którym sporządzane były mikrofilmy, akta te znajdowały się w Kielcach i w drukowanym katalogu Ośrodka ABMK podawano je wówczas pod archiwum kieleckim.

Mikrofilmy archiwaliów krakowskich autorka podzieliła na grupy i zespoły (s. 22 i n.). Mamy więc kolekcję nazwaną Kancelarie Biskupów Krakowskich. W kolekcji tej znajdują się nowożytne akta wizytacyjne, traktowane w Krakowie jako swego rodzaju seria/kolekcja. Podobnie rzecz ma się z kolekcją nazwaną w katalogu przez autorkę Akta czynności biskupów krakowskich. W skład tej grupy wchodzą acta episcopalia, księgi święceń, protokoły korespondencji bp. Kajetana Sołtyka z Gubernium Lwowskim. Z kolei akta oficjałów krakowskich - acta officialia - od połowy XVI w. do pierwszej połowy XVII w. traktowane są jako zespół o nazwie Kancelaria Oficjała Generalnego w Krakowie. Niekonsekwentne traktowanie zespołów w wielu archiwach kościelnych wynika z utartej praktyki, która doprowadziła do wytworzenia zespołów i kolekcji poprzez nadanie ciągu sygnatur poszczególnym jednostkom. Praktyki te weszły do obiegu naukowego i trudno dziś to zmieniać. Teoria archiwistyczna może w niektórych wypadkach biec obok praktyki i jedynie dociekać kwestii kancelaryjnych.

Praca autorki nad przygotowaniem opisów i nadaniem im struktury była uwarunkowana zwyczajami różnych archiwów i utrwalonym układem poprzednich drukowanych katalogów mikrofilmów Ośrodka ABMK. Jednak w ramach własnej pracy można było nieco bardziej ujednolicić nazwy zespołów. Mikrofilmy akt archiwum kieleckiego autorka uszeregowała tam, gdzie to było możliwe, w zespoły archiwalne - poszczególne kapituły i oficjalaty. Grupę nowożytnych protokołów wizytacyjnych dawnej diecezji krakowskiej nazwała Wizytacje kościołów i parafii (s. 17-18). Grupa ta jest kolekcją stworzoną z akt wizytacyjnych dawnej diecezji krakowskiej. Stanowi część olbrzymiej kolekcji kancelaryjnej i archiwalnej ksiąg wizytacyjnych przechowywanych w Krakowie. Faktycznie 
trudno w tym przypadku, bez badań i wypracowania teorii, określić nazwę zespołu.

Problem zespołowości jest natomiast łatwy do rozwiązania w odniesieniu do mikrofilmów grupy archiwaliów Archiwum Diecezjalnego w Kielcach, które autorka nazwała Parafie (s. 21-22). Konsekwentnie należało nadać poszczególnym jednostkom nazwy utworzone od instytucji: Parafia Goleniowy, Parafia Goszcza itd. Podobnie należało rozstrzygnąć ten problem w odniesieniu do innych tego typu przypadków. W katalogu występują mikrofilmy dwóch jednostek archiwalnych z Archiwum Archidiecezjalnego w Białymstoku (s. 15). Ten niewielki zbiór nazwany został Parafie. Tytuły jednostek wskazują jednak, że są to poszyty jednej parafii Dobrzyniewo w dawnej diecezji wileńskiej. W tej sytuacji mamy tu do czynienia po prostu z jednym zespołem. Zespół ten powinien nazywać się Parafia Dobrzyniewo.

Występują też przypadki niekonsekwentnego nazywania zespołów, szczególnie oficjalatów: Kancelaria Oficjała Generalnego w Krakowie (s. 58), Konsystorz Generalny we Lwowie (nowego typu, XIX-XX w.) (s. 79), Akta Oficjałów Okręgowych w Lublinie (s. 127). Zastosowane nazewnictwo jest skrzyżowaniem praktyki archiwów oraz ustaleń Ośrodka ABMK podjętych po zmikrofilmowaniu i decyzji uszeregowania opisów w drukowanym katalogu. Być może poprawne byłoby zastosowanie następujących tytułów: Oficjalat Generalny w Krakowie, Konsystorz Generalny we Lwowie (nowego typu, XVIII-XX w.), Oficjalat Okręgowy w Lublinie.

Katalog opatrzony jest indeksem osobowym i geograficznym. Indeks osobowy zawiera niemal wszystkie osoby, które występują w tytułach jednostek archiwalnych. Indeks geograficzny obejmuje miejscowości, do których odnoszą się archiwalia. Jeśli dana miejscowość występuje w tytule jednostki, odnoszącej się np. do wizytacji parafii w tej miejscowości, to została ona wykazana w indeksie. Indeks osobowy podaje poszczególne urzędy osób z uwzględnieniem ich zmieniających się stopni kariery kościelnej, co wymagało dużej precyzji i benedyktyńskiej pracy. Ogrom wysiłku włożonego w indeksy nie pozwolił jednak uniknąć drobnych niedociągnięć. Przykładowe błędy i braki: „Bieroński scholastyk kielecki” - nie podano imienia, dość łatwego do ustalenia7; błędnie „Droginia" - powinno być Drugnia; Jana Pawła Woronicza określono jako biskupa warszawskiego, a był arcybiskupem warszawskim.

Twórczyni katalogu, M. Dębowska, posiada znaczący dorobek naukowy ${ }^{8}$. W polskiej archiwistyce wyróżnia się jako autorka informatora o archiwach

${ }^{7}$ W. Firlej, Bieroński Nestor Hygin Soter, [w:] Bibliografia piśmiennictwa profesorów seminarium kieleckiego (1727-2001). Księga jubileuszowa, oprac. D. Krześniak-Firlej, W. Firlej, A. Kaleta, Kielce 2002, s. 19-22.

${ }^{8}$ MARIA DĘBOWSKA Oficjalna strona. Publikacje, http://www.mariadebowska.pl/index.php/ pl/publikacje [dostęp 24.06.2020]. 
kościelnych wydanego na łamach $\mathrm{ABMK}^{9}$, a następnie w formie książkowej ${ }^{10}$. Wiele jej artykułów dotyczy problematyki ogólnopolskiej archiwów kościelnych $^{11}$. Ważne są jej publikacje na temat archiwaliów z okresu dwudziestolecia międzywojennego ${ }^{12}$. Kilka prac odnosi się do archiwów parafialnych ${ }^{13}$. Praktyczne opracowania poświęciła archiwom parafialnym i zakonnym w Miechowie i Imbramowicach. Prace te były związane z procesem mikrofilmowania zasobu tych archiwów ${ }^{14}$. Podejmowała kluczową, lecz ciągle mało zrozumiałą w polskiej archiwistyce kościelnej, zasadę zespołowości ${ }^{15}$. Opracowanie katalogu mikrofilmów Ośrodka ABMK stanowi w jej dorobku w pewnym sensie podsumowanie aktywności zawodowej. Ważniejsze jest jednak to, że - poprzez wieloletnią pracę i nabyte doświadczenie teoretyczne i praktyczne - zdobyła kwalifikacje umożliwiające opracowanie katalogu. Te okoliczności predestynowały ją niejako do opracowania katalogu mikrofilmów.

Wobec słabego zinwentaryzowania zasobu archiwów kościelnych, autorka wykonała pracę poprawienia opisów jednostek archiwalnych i teoretycznego dzielenia kolekcji na zespoły. Wiele zmikrofilmowanych jednostek archiwalnych nie posiada nawet sygnatur nadanych przez archiwa. Oczekiwanie na uporządkowanie zasobu archiwów kościelnych nie byłoby jednak korzystne dla Ośrodka ABMK i autorki katalogu. Praca w takich warunkach wiązała się z koniecznością uporania się z licznymi problemami i w konsekwencji z podjęciem wielu decyzji metodycznych. Krytyczne uwagi, odnoszące się do szczegółów,

${ }^{9}$ M. Dębowska, Informator o archiwach Kościoła katolickiego w Polsce. Archiwa diecezjalne $i$ archiwa kapitut katedralnych, ABMK 1995, t. 64, s. 365-431; eaedem, Informator o archiwach zakonnych w Polsce, ibidem, t. 68, s. 15-99.

${ }^{10}$ Archiwa Kościoła katolickiego w Polsce. Informator, oprac. M. Dębowska, Lublin 2002.

${ }^{11}$ Eadem, Archiwa Kościoła katolickiego w ostatnim stuleciu, [w:] Nova et vetera. Aktualne problemy archiwów diecezjalnych w Polsce, red. W. Żurek, Lublin 2016, s. 23-43; eadem, Stan badań nad kancelariami kościelnymi, „Archiva Ecclesiastica” 2007, nr 4, s. 7-18.

${ }^{12}$ Eadem, Archiwa Kościoła katolickiego w II Rzeczypospolitej, ABMK 2009, t. 92, s. 39-51; Kurie (archi)diecezjalne Kościoła rzymskokatolickiego w II Rzeczypospolitej, red. M. Dębowska, Lublin 2016; eadem, A. Hamryszczak, Inwentarz Archiwum Diecezji Łuckiej, Kraków 2018; eadem, Losy materiatów archiwalnych ze wschodnich diecezji II Rzeczypospolitej ze szczególnym uwzględnieniem archiwaliów diecezji tuckiej, [w:] Archiwa kościelne w stużbie społeczeństwu, red. M. Różański, Łódź 2014, s. 121-130.

${ }^{13}$ Eadem, Księga zapowiedzi łacińskiej parafii katedralnej w Łucku 1782-1826, Lublin 2013; eadem, Stan badań nad archiwami parafialnymi w Polsce, ABMK 2001, t. 75, s. 11-17; eadem, Status animarum łacińskiej parafii katedralnej_w Łucku 1815-1819, Lublin 2013.

${ }^{14}$ Eadem, R. Skrzyniarz, Materiały do dziejów bożogrobców w Archiwum Parafialnym w Miechowie, ABMK 2006, t. 86, s. 83-106; eadem, Archiwum Norbertanek w Imbramowicach, ABMK 2010, t. 94, s. 29-38; eadem, Poszanowanie zasady przynależności zespołowej w archiwach Kościoła katolickiego w Polsce - problem rzeczywisty czy wydumany?, „Archiva Ecclesiastica” 2005. nr 2, s. $5-12$.

${ }^{15}$ Eadem, Problem zespołowości w praktyce archiwów kościelnych w Polsce, ABMK 81 (2004), s. 49-57; eadem, Akta wizytacyjne w strukturze zasobów historycznych archiwów diecezjalnych $w$ Polsce, ibidem 2012, t. 97, s. 65-71. 
nie wpływają na ocenę całości doniosłego dzieła. Często proponowane przez autorkę zmiany być może należy uznać za sposobność do dyskusji. Jeśli chodzi o błędy, to w większości należy je przypisać nie M. Dębowskiej, a inwentarzom archiwów kościelnych. Poprzez zebranie opisów archiwaliów, katalog wskazuje na najważniejsze polskie zbiory kościelne. Analogicznie, indeks osobowy jest zestawieniem istotniejszych urzędników Kościoła w Polsce, a indeks geograficzny - wykazem miejscowości, w których działały historyczne instytucje kościelne. Te fakty nadają katalogowi charakter ogólnopolskiego zestawienia. Wobec skromnej literatury przedmiotu na temat zasobu archiwów i bibliotek kościelnych, dzięki pracy Ośrodka ABMK i katalogowi M. Dębowskiej, zarysowuje się ułatwiona możliwość praktycznego uzyskania wiedzy o staropolskim zasobie archiwów kościelnych. Nauka polska uzyskała w ten sposób uporządkowaną wiedzę na miarę dzisiejszych możliwości.

Usystematyzowana wiedza pozwala na zdobycie orientacji w najważniejszych archiwaliach kościelnych. Tworzenie narracji wykładowej o zasobie polskich archiwów kościelnych pozostaje ciągle w związku z podręcznikiem ojca profesora Hieronima Eugeniusza Wyczawskiego ${ }^{16}$. Znajdujemy w nim najobszerniejszą narrację i najbardziej całościowe wyjaśnienie zagadnień archiwistyki kościelnej w Polsce. Ponadto polska archiwistyka kościelna cieszy się informatorem autorstwa M. Dębowskiej wydanym w 2002 r. W publikacji przy każdym archiwum podano ogólną notatkę na temat zasobu ${ }^{17}$. Cenne opisy zamieszczone $\mathrm{w}$ informatorze były sporządzane $\mathrm{z}$ danych przesłanych przez instytucje kościelne do autorki, w niektórych wypadkach stosunkowo lakonicznych. Informacje zawarte w Katalogu mikrofilmów... to opisy poszczególnych jednostek archiwalnych uszeregowanych w grupach, zwykle według sygnatur, co często wskazuje pośrednio na kwestię związków kancelaryjnych. Zestawienie danych z Katalogu mikrofilmów... z podręcznikiem ojca H.E. Wyczawskiego oraz z informatorem M. Dębowskiej pozwala na łatwiejsze uzyskanie wiedzy, dotąd trudno dostępnej.

Mikrofilmy kościelnych zbiorów liturgicznych i bibliotecznych obejmują dużą część średniowiecznych i nowożytnych rękopisów liturgicznych. Umożliwia to badania nad polskim chorałem diecezjalnym i zakonnym. Zmikrofilmowane starodruki liturgiczne pozwalają na uchwycenie końcowego etapu rozwoju polskiej liturgii tuż przed reformą trydencką. Zmikrofilmowane egzemplarze ksiąg chorału piotrkowskiego ocaliły, często unikatowe, egzemplarze tego typu druków, które nierzadko przechowywane są w kilku zaledwie egzemplarzach w Polsce, często w bibliotekach parafialnych nie posiadających żadnych zabezpieczeń. Jedyną ochroną jest $\mathrm{w}$ tych instytucjach ignorancja kolekcjonerów, nie posiadających wiedzy o miejscowości, w której przechowywany jest unikatowy

${ }^{16}$ H.E. Wyczawski, Przygotowanie do studiów w archiwach kościelnych, wyd. 2, red. T. Moskal, A.K. Sitnik, Kalwaria Zebrzydowska 2013.

${ }^{17}$ Archiwa Kościola katolickiego w Polsce. Informator, op.cit. 
druk z XVII lub XVIII w. Przykładowo: jeżeli występują obecnie dwa egzemplarze danego wydania antyfonarza piotrkowskiego, $w$ tym jeden egzemplarz jest $\mathrm{w}$ bibliotece o znamionach publicznych, a drugi w bibliotece parafialnej i wykonany został mikrofilm egzemplarza z biblioteki publicznej, to może się on okazać mikrofilmem unikatu. Egzemplarz z biblioteki parafialnej może w każdej chwili zniknąć. Nie ma pewności, czy w danym momencie jeszcze istnieje. Mikrofilmy ksiąg chorału piotrkowskiego pozwalają na badania polskiej twórczości liturgicznej po Soborze Trydenckim. Obok ksiąg liturgicznych na prowadzenie badań także pozwalają mikrofilmy rękopisów i druków teologicznych oraz prawnych. W odniesieniu do druków synodów mamy w Ośrodku ABMK kolekcję o znamionach reprezentatywności.

\section{Źródla}

Archiwum Ośrodka Archiwów, Bibliotek i Muzeów Kościelnych, Mikrofilmowanie archiwaliów, Skontrum mikrofilmów OABMK 2015-2016, b. sygn.

\section{Bibliografia}

Archiwa Kościoła katolickiego w Polsce. Informator, oprac. M. Dębowska, Lublin 2002.

Dębowska M., Akta wizytacyjne w strukturze zasobów historycznych archiwów diecezjalnych w Polsce, „Archiwa, Biblioteki i Muzea Kościelne” 2012, t. 97, s. 65-71.

Dębowska M., Archiwa Kościoła katolickiego w ostatnim stuleciu, [w:] Nova et vetera. Aktualne problemy archiwów diecezjalnych w Polsce, red. W. Żurek, Lublin 2016, s. 23-43.

Dębowska M., Archiwa Kościoła katolickiego w II Rzeczypospolitej, „Archiwa, Biblioteki i Muzea Kościelne" 2009, t. 92 s. 39-51.

Dębowska M., Archiwum Norbertanek w Imbramowicach, „Archiwa, Biblioteki i Muzea Kościelne" 2010, t. 94, s. 29-38.

Dębowska M., Informator o archiwach Kościoła katolickiego w Polsce. Archiwa diecezjalne i archiwa kapitut katedralnych, „Archiwa, Biblioteki i Muzea Kościelne”, 1995, t. 64, s. 365-431.

Dębowska M., Informator o archiwach zakonnych w Polsce, „Archiwa, Biblioteki i Muzea Kościelne" 1998, t. 68, s. 15-99.

Dębowska M., Hamryszczak A., Inwentarz Archiwum Diecezji Łuckiej, Kraków 2018.

Dębowska M., Księga zapowiedzi lacińskiej parafii katedralnej w Łucku 1782-1826, Lublin 2013.

Dębowska M. Losy materiatów archiwalnych ze wschodnich diecezji II Rzeczypospolitej ze szczególnym uwzględnieniem archiwaliów diecezji łuckiej, [w:] Archiwa kościelne w stużbie społeczeństwu, red. M. Różański, Łódź 2014, s. 121-130.

Dębowska M., Mikrofilmowanie zbiorów kościelnych w Instytucie Archiwów, Bibliotek i Muzeów Kościelnych Katolickiego Uniwersytetu Lubelskiego Jana Pawła II, [w:] Archiwa w nowoczesnym spoleczeństwie. Pamiętnik V Powszechnego Zjazdu Archiwistów Polskich Olsztyn 6-8 września 2007 r., red. J. Porazinski, K. Stryjkowski, Warszawa 2008, s. 109-116. 
Dębowska M., Mikrofilmowanie materiałów archiwalnych w archiwach kościelnych, [w:] Ochrona zasobu archiwów kościelnych, red. A. Laszuk, Warszawa 2012, s. 160-169.

Dębowska M., Poszanowanie zasady przynależności zespołowej $w$ archiwach Kościoła katolickiego w Polsce - problem rzeczywisty czy wydumany?, „Archiva Ecclesiastica” 2005, nr 2, s. $5-12$.

Dębowska M., Problem zespołowości w praktyce archiwów kościelnych w Polsce, „Archiwa, Biblioteki i Muzea Kościelne" 2004, t. 81, s. 49-57.

Dębowska M., Skrzyniarz R., Materiały do dziejów bożogrobców w Archiwum Parafialnym w Miechowie, „Archiwa, Biblioteki i Muzea Kościelne” 2006, t. 86, s. 83-106.

Dębowska M., Stan badań nad archiwami parafialnymi w Polsce, „Archiwa, Biblioteki i Muzea Kościelne" 2001, t. 75, s. 11-17.

Dębowska M. Stan badań nad kancelariami kościelnymi, „Archiva Ecclesiastica” 2007, nr 4, s. $7-18$.

Dębowska M., Status animarum tacińskiej parafii katedralnej w Łucku 1815-1819, Lublin 2013.

Firlej W., Bieroński Nestor Hygin Soter, [w:] Bibliografia piśmiennictwa profesorów seminarium kieleckiego (1727-2001). Księga jubileuszowa, oprac. D. Krześniak-Firlej, W. Firlej, A. Kaleta, Kielce 2002, s. 19-22.

Kumor B., Mikrofilmowanie zbiorów kościelnych przez Ośrodek Archiwów, Bibliotek i Muzeów Kościelnych, „Archiwa, Biblioteki i Muzea Kościelne” 1980, t. 40, s. 119-122.

Kumor B., Rola Ośrodka Archiwów, Bibliotek i Muzeów Kościelnych przy KUL w udostępnianiu kościelnych zbiorów archiwalnych nauce polskiej, [w:] Materiały sesji „Archiwa warsztatem pracy historyka", cz. 2, Torun 1972, s. 69-73.

Kurie (archi)diecezjalne Kościoła rzymskokatolickiego w II Rzeczypospolitej, red. M. Dębowska, Lublin 2016.

Kwaśniewski A., Podręczniki do historii Kościoła i wybrane monografie księdza profesora Bolestawa Kumora, [w:] Ksiadz profesor Bolesław Kumor 1925-2002. Historyk Kościoła i dydaktyk, red. W. Żurek, Lublin 2018, s. 53-76.

Wyczawski H.E., Przygotowanie do studiów $w$ archiwach kościelnych wyd. 2, red. T. Moskal, A. K. Sitnik, Kalwaria Zebrzydowska 2013. 